Jurnal Ilmiah Matematika dan Pendidikan Matematika (JMP)

Vol. 9 No. 2, Desember 2017, hal. 95-110

ISSN (Cetak) : 2085-1456; ISSN (Online) : 2550-0422; https://jmpunsoed.com/

\title{
METODE SSA PADA DATA PRODUKSI PERIKANAN TANGKAP DI PROVINSI JAWA BARAT
}

\author{
Fadhilah Fitri \\ Program Studi Magister Statistika Terapan, Universitas Padjadjaran \\ fadhilahfitri14@gmail.com \\ Nurul Fiskia Gamayanti \\ Program Studi Magister Statistika Terapan, Universitas Padjadjaran \\ Gumgum Darmawan \\ Program Studi Magister Statistika Terapan, Universitas Padjadjaran
}

\begin{abstract}
Indonesia is an archipelagic country where $2 / 3$ of its territory is ocean. The vastness of Indonesia's oceans is expected to produce abundant sea products that can meet the needs of Indonesian consumers, especially fish. Adequacy of the amount of fish consumption can be assessed through the number of fish catch. Based on data at the Ministry of Marine Affairs and Fisheries in 2015, West Java has a low growth of fish consumption, 6.05\% in 2010-2014. Therefore, it is necessary to forecast the results of fish catch for several years ahead so it can be known whether the provision of fish consumption will be fulfilled or not. One method that can be used is Singular Spectrum Analysis (SSA). The SSA method is a flexible method because it uses a nonparametric approach. That is, in its application, this method does not require the model specification of time series data, as well as parametric assumptions. Forecasting accuracy of a method is said to be good if it has a MAPE value less than 20\%. MAPE of SSA method forecast is $6.19 \%$ so that SSA method is suitable for forecasting of capture fishery production in West Java Province. The forecast for fishery production in West Java Province in 2015 for the first, second, third, and fourth quarter were 53,978.49 Ton, 54,406.91 Ton, 50,889.11 Ton, and 56,896.96 Ton, respectively.
\end{abstract}

Keywords: Capture fisheries, SSA, MAPE

\begin{abstract}
ABSTRAK. Indonesia merupakan negara kepulauan di mana 2/3 wilayahnya merupakan lautan. Luasnya daerah lautan Indonesia diharapkan dapat memberikan hasil laut yang berlimpah sehingga dapat memenuhi kebutuhan konsumsi masyarakat Indonesia, khususnya ikan. Kecukupan jumlah penyediaan konsumsi ikan dapat dinilai salah satunya melalui jumlah hasil tangkap ikan. Berdasarkan data pada Kementerian Kelautan dan Perikanan tahun 2015, Jawa Barat merupakan salah satu provinsi yang memiliki pertumbuhan penyediaan konsumsi ikan yang rendah yaitu $6.05 \%$ pada tahun 2010-2014. Oleh karena itu, perlu dilakukan peramalan mengenai hasil tangkap ikan untuk beberapa tahun ke depan sehingga dapat diketahui apakah penyediaan konsumsi ikan akan tercukupi atau tidak. Salah satu metode yang dapat digunakan adalah Singular
\end{abstract}


Spectrum Analysis (SSA). Metode SSA merupakan metode yang fleksibel karena menggunakan pendekatan non-parametrik. Artinya, dalam pengaplikasiannya, metode ini tidak membutuhkan spesifikasi model dari data deret waktu, serta asumsi-asumsi parametrik. Akurasi peramalan sebuah metode dikatakan baik apabila memiliki nilai MAPE kurang dari 20\%. MAPE dari ramalan metode SSA adalah 6.19\% sehingga metode SSA cocok digunakan pada peramalan produksi perikanan tangkap di Provinsi Jawa Barat. Hasil ramalan untuk produksi perikanan tangkap di Provinsi Jawa Barat tahun 2015 untuk kuartal I adalah 53.978,49 Ton, kuartal II adalah 54.406,91 Ton, kuartal III adalah 50.889,11 Ton, dan kuartal IV adalah 56.896,96 Ton.

Kata Kunci: Perikanan tangkap, SSA, MAPE.

\section{PENDAHULUAN}

Indonesia merupakan negara kepulauan dimana 2/3 wilayahnya merupakan lautan. Daerah lautan Indonesia yang luas diharapkan dapat menghasilkan hasil laut yang sangat berlimpah sehingga dapat memenuhi kebutuhan masyarakat Indonesia dalam mengkonsumsi hasil laut khususnya ikan. Ikan merupakan salah satu hasil laut yang merupakan sumber protein hewani bagi masyarakat Indonesia. Namun kenyataannya, tingkat konsumsi ikan masyarakat Indonesia masih rendah jika dibandingkan dengan negara-negara maju lainnya.

Jumlah penyediaan konsumsi ikan diharapkan lebih besar daripada tingkat konsumsi ikan dan diikuti dengan trend naik untuk setiap tahunnya. Pada lima tahun terakhir, terjadi peningkatan yang cukup signifikan terhadap konsumsi ikan masyarakat Indonesia. Hal ini tidak terlepas dari dukungan berbagai pihak dalam mensosialisasikan pentingnya mengkonsumsi ikan kepada masyarakat. Sehingga diharapkan ke depannya jumlah penyediaan konsumsi ikan akan selalu mencukupi permintaan masyarakat. Kecukupan jumlah penyediaan konsumsi ikan dapat dinilai salah satunya melalui jumlah hasil tangkap ikan di laut.

Berdasarkan data Kementerian Kelautan dan Perikanan pada tahun 2015, Jawa Barat merupakan salah satu provinsi yang memiliki pertumbuhan penyediaan konsumsi ikan yang rendah yaitu 6.05\% dari tahun 2010 - 2014 . Oleh karena itu, perlu dilakukan peramalan terhadap hasil tangkap ikan di Provinsi Jawa Barat di tahun-tahun berikutnya sehingga dapat diketahui apakah ketersediaan ikan akan memenuhi kebutuhan konsumsi masyarakat atau tidak. 
Salah satu metode yang dapat digunakan adalah metode Singular Spectrum Analysis (SSA). Metode SSA merupakan metode yang fleksibel karena menggunakan pendekatan non-parametrik. Artinya, dalam pengaplikasiannya, metode ini tidak membutuhkan spesifikasi model dari data deret waktu, serta asumsi-asumsi parametric, sehingga diharapkan metode SSA dapat memberikan hasil peramalan yang akurat. Namun, data yang digunakan harus memiliki efek musiman.

Jumlah hasil tangkap ikan di Provinsi Jawa Barat ini sebelumnya juga pernah diramalkan menggunakan Autoregressive Distributed Lag Modelling (ARDL) dengan melibatkan curah hujan sebagai variabel bebas (Fitri, 2016). Pada penelitian tersebut didapatkan nilai keakuratan model, dalam hal ini penulis menggunakan MAPE, yaitu sebesar $16.21 \%$.

\section{METODE PENELITIAN}

\subsection{Data}

Data yang digunakan pada penelitian ini adalah data sekunder yang diambil dari Dinas Perikanan dan Kelautan Provinsi Jawa Barat dari kuartal satu tahun 2004 sampai dengan kuartal empat tahun 2014.

\subsection{Algoritma Singular Spectrum Analysis}

Singular Spectrum Analysis adalah suatu teknik nonparametrik yang digunakan untuk mengamati suatu data deret waktu yang tidak linier, tidak stasioner, dan memiliki sifat berubah-ubah setiap saat ataupun sementara (Khan dan Poskitt, 2011).

\subsubsection{Dekomposisi}

Dekomposisi adalah tahapan awal pada Singular Spectrum Analysis yang melibatkan komponen trend, musiman, siklis, dan error pada peramalan. Dekomposisi terdiri dari dua tahapan yaitu embedding dan Singular Value Decomposition (SVD). 


\subsubsection{Embedding}

Embedding adalah tahapan di mana data deret waktu awal diubah menjadi matriks trajectory, maksudnya mengubah data awal yang berupa data satu dimensi menjadi data berbentuk multidimensi. Matriks trajectory memiliki dimensi $L x K$, di mana $L$ merupakan window length menjadi baris matriks, sedangkan $K=N-L+1$ menjadi kolom matriks. Rentang pemilihan nilai $L$ adalah $2<L<\frac{N}{2}$, serta asumsi bahwa data deret waktu sepanjang periode $N$ tidak mengandung data hilang, serta $X=\left\{x_{i}\right\} ; i=1,2, \ldots, N$ (Golyandina, 2001).

Matriks trajectory $\left(T_{x}\right)$ yang terbentuk merupakan matriks Hankel. Matriks Hankel adalah matriks yang semua elemen di sepanjang diagonal $i+j$ konstan. Matriks trajectory dapat ditulis sebagai berikut:

$$
T_{x}=\left(T_{i, j}\right)_{L \times K}=\left[\begin{array}{cccc}
x_{1} & x_{2} & \ldots & x_{K} \\
x_{2} & x_{3} & \ldots & x_{K+1} \\
\vdots & \vdots & \ddots & \vdots \\
x_{L} & x_{L+1} & \ldots & x_{N}
\end{array}\right]
$$

\subsubsection{Singular Value Decomposition}

Singular Value Decomposition bertujuan untuk memperoleh pemisahan komponen dalam dekomposisi dari data deret waktu. Singular Value Decomposition pada penerapannya memiliki kesamaan dengan analisis komponen utama (principal component analysis) yaitu bersifat untuk mereduksi komponen dari data awal serta mengurangi dimensi.

Singular Value Decomposition dimulai dengan menentukan nilai eigenvalue $\left(\lambda_{1}, \lambda_{2}, \ldots, \lambda_{L}\right)$ dari matriks $S=T_{X} T_{X}{ }^{T}$ di mana $\lambda_{1} \geq \cdots \geq \lambda_{L}>0$, serta eigenvector $\left(U_{1}, U_{2}, \ldots, U_{L}\right)$ dari matriks $\mathrm{S}$ tersebut. Singular Value Decomposition pada Matriks trajectory $T_{x}$ akan menghasilkan:

$$
T_{x i}=U_{i} D_{i} V_{i}^{\prime} .
$$

di mana

$U_{i}$ : matriks ortonormal $K \times L$

$D_{i}:$ matriks diagonal orde $L$

$V_{i}=\frac{X^{T} U_{i}}{\sqrt{\lambda_{i}}}:$ matriks ortonormal bujursangkar $L \times L$ 
sehingga menghasilkan:

$$
T_{x i}=\sum_{i=1}^{d} \sqrt{\lambda_{i}} U_{i} V_{i}^{T}
$$

dengan $i=1,2, \ldots, d$ dan $d=\max \{i\} ; \lambda_{i}>0$.

Ketiga komponen dalam matriks $T_{x i}$ yaitu singular value $\left(\sqrt{\lambda_{i}}\right)$, eigenvector $\left(U_{i}\right)$, dan principal component $\left(V_{i}\right)$ disebut eigentriple ke- $i$ dari Singular Value Decomposition. Selanjutnya, Singular Value Decomposition untuk trajectory matrix $T_{x i}$ dapat dituliskan sebagai berikut:

$$
T_{x i}=T_{x 1}+T_{x 2}+\cdots+T_{x d}
$$

\subsubsection{Rekonstruksi}

Rekonstruksi adalah tahapan di mana data direkonstruksi menjadi data deret waktu yang baru berdasarkan nilai-nilai yang diperoleh pada tahap sebelumya pada tahap dekomposisi melalui proses grouping dan diagonal averaging.

\subsubsection{Grouping}

Grouping adalah tahapan pemisahan komponen-komponen aditif seperti trend, seasonal, bulanan, dan noise yang terdapat pada data deret waktu. Proses grouping dilakukan dengan cara mengelompokkan set-set indeks $\{1,2, \ldots d\}$ menjadi $m$ subset yang dapat dilambangkan dengan $I=I_{1}, I_{2}, \ldots, I_{m}$ yang selanjutnya membentuk matriks yang didasarkan pada Singular Value Decomposition untuk trajectory matrix $T_{x i}$ sebagai berikut:

$$
T_{I x}=T_{I 1}+T_{I 2}+\ldots+T_{I m}
$$

Tahapan untuk memilih set $I=I_{1}, I_{2}, \ldots, I_{m}$ disebut dengan eigentriple grouping.

\subsubsection{Diagonal Averaging}

Diagonal averaging merupakan tahapan terakhir pada Singular Spectrum Analysis. Tahapan diagonal averaging ini adalah tahapan merekonstruksi masingmasing matriks yang terdapat pada matriks $T_{I x}$ menjadi data deret waktu yang baru dengan panjang $\mathrm{N}$. 
Misalkan matriks $Y=L \times K ; y_{i j}, 1 \leq i \leq L, 1 \leq j \leq K$. Matriks $Y$ diubah menjadi deret waktu $g_{0}, \ldots, g_{N-1}$ melalui diagonal averaging yaitu:

$$
g_{k}=\left\{\begin{array}{l}
\frac{1}{k+1} \sum_{m=1}^{k+1} y_{m, k-m+2}^{*} ; 0 \leq k<L^{*}-1 \\
\frac{1}{L^{*}} \sum_{m=1}^{L^{*}} y_{m, k-m+2}^{*} ; L^{*}-1 \leq k<K^{*} \\
\frac{1}{N-k} \sum_{m=k-K^{*}+2}^{N-K^{*}+1} y_{m, k-m+2}^{*} ; K^{*} \leq k<N
\end{array}\right.
$$

dengan

$$
\begin{gathered}
L^{*}=\min (L, K) ; K^{*}=\max (L, K) \\
N=L+K-1 \\
y_{i j}^{*}=\left\{\begin{array}{c}
y_{i j} ; L<K \\
y_{j i} ; \text { selainnya }
\end{array}\right.
\end{gathered}
$$

dan $g_{k}$ merupakan rata-rata dari elemen matriks di sepanjang diagonal $i+j=$ $k+2$. Untuk $k=0$ akan dihasilkan bahwa $g_{0}=y_{11}, k=1$ akan dihasilkan bahwa $g_{1}=\frac{\left(y_{12}+y_{21}\right)}{2}$, dan seterusnya.

\subsubsection{Peramalan}

Peramalan hasil tangkap ikan di daerah Jawa Barat menggunakan $R$ forecasting. Peramalan R-Forecasting berkaitan dengan penaksiran Linier Recurrent Formula (LRF); yaitu $a_{1}, \ldots, a_{d}$ yang merupakan eigenvectors yang diperoleh dari tahapan SVD. Apabila dimisalkan $\mathrm{U}=\left(u_{1}, u_{2}, \ldots, u_{L-1}, u_{L}\right)^{T}$, $U^{\nabla}=\left(u_{1}, u_{2}, \ldots, u_{L-1}\right)^{T}$, dan $\pi_{i}$ adalah komponen terakhir dari eigenvectors $\mathrm{U}$ atau dapat ditulis $\pi_{i}=u_{L}$ maka koefisien LRF dapat dihitung menggunakan persamaan

$$
\Re=\mathrm{U}=\left(a_{L-1}, u_{L-2}, \ldots, a_{2}, u_{1}\right)^{T}=\frac{1}{1-v^{2}} \sum_{i=1}^{r} \pi_{i} U_{t}^{\nabla}
$$

dengan $v^{2}=\sum_{i=1}^{r} \pi_{i}^{2}$. 
Data deret waktu yang digunakan pada $R$-forecasting merupakan hasil rekonstruksi yang diperoleh dari diagonal averaging. Langkah selanjutnya yaitu menentukan $M$ buah titik baru untuk diramalkan. Sehingga deret hasil peramalan dapat ditunjukkan oleh

$$
G_{N+M}=\left(g_{1}, \ldots, g_{N+M}\right)
$$

Hasil peramalan diperoleh berdasarkan

$$
g_{k}=\left\{\begin{array}{c}
\overline{y_{l}} ; i=0,1, \ldots N \\
\sum_{j=1}^{L-1} a_{j} g_{i-j} ; i=N+1, \ldots, N+M
\end{array}\right.
$$

\subsection{Menentukan Akurasi Peramalan}

\subsubsection{Ukuran Akurasi MAPE}

Akurasi peramalan pada penelitian ini menggunakan nilai Mean Absolute Percentage Error (MAPE).

$$
M A P E=\frac{\sum_{i=1}^{t}\left|\left(\frac{x_{t}-F_{t}}{X_{t}}\right) \cdot 100 \%\right|}{N}
$$

dengan

$X_{t}$ : data deret waktu aktual

$F_{t}:$ data hasil peramalan

Ketika menganalisis kesalahan suatu metode peramalan yang digunakan, sebaiknya MAPE dihitung karena lebih mudah untuk diinterpretasikan nilainya yang merupakan presentase dari keseluruhan. Interpretasi nilai MAPE dapat dilihat pada Tabel 1 .

Tabel 1. Interpretasi Nilai MAPE

\begin{tabular}{|c|l|}
\hline MAPE & \multicolumn{1}{|c|}{ Interpretasi } \\
\hline$<10$ & Peramalan dengan akurasi tinggi \\
\hline $10-20$ & Peramalan yang baik \\
\hline $20-30$ & Peramalan yang layak \\
\hline$>50$ & Peramalan yang tidak akurat \\
\hline
\end{tabular}

(Sumber: Lewis, 1982)

\subsubsection{Ukuran Akurasi Tracking Signal}

Salah satu alat pengukuran akurasi peramalan lainnya untuk data deret waktu adalah nilai tracking signal. Tracking signal adalah ukuran toleransi yang 
dapat digunakan untuk menentukan kemungkinan apakah hasil dari peramalan dapat digunakan. Batas toleransi dari nilai tracking signal yang dapat diterima yaitu \pm 5 (Bovas dan Ledolter,1983)

$$
\text { Tracking Signal }=\frac{\sum_{1}^{n} e_{n}}{\sum_{1}^{n} \frac{e_{n} \mid}{n}}
$$

\section{HASIL DAN PEMBAHASAN}

\subsection{Perhitungan Window Length (Nilai $L$ )}

Penentuan window length (nilai $L$ ) sangatlah penting dalam metode Singular Spectrum Analysis (SSA). Window length (nilai L) merupakan dimensi dari matriks trajectory dari data. Pada penelitian ini penetuan Window length (nilai $L$ ) dilakukan berdasarkan proses trial and error. Dari 44 data yang ada, dilakukan pengecekan trial and error sehingga mendapatkan nilai $L$ yang sesuai.

\subsection{Dekomposisi}

Tahapan dekomposisi melibatkan 2 tahapan yaitu tahapan embedding dan Singular Value Decomposition.

a. Embedding

Tahapan embedding adalah tahapan dimana data awal yang berupa data satu dimensi diubah menjadi sebuah data yang berbentuk multidimensi hal ini dilakukan dengan cara membentuk matriks trajectory yang berdimensi $L \times K$. Pada penelitian ini Window length (nilai $L$ ) yang digunakan adalah 20 yang didapatkan dari hasil trial and error. Sehingga nilai $K=N-L+1=40-20+1=21$. Matriks trajectory yang akan terbentuk berdimensi $20 \times 21$. Bentuk matriks trajectory-nya adalah sebagai berikut:

$$
\left(T_{i, j}\right)_{20 \times 21}=\left[\begin{array}{cccc}
40221.61 & 42671.50 & \ldots & 48522.30 \\
42671.50 & 33255.70 & \ldots & 43228.24 \\
\vdots & \vdots & \ddots & \vdots \\
48522.30 & 43228.24 & \ldots & 55420.17
\end{array}\right]
$$


b. Singular Value Decomposition

Matriks trajectory yang dihasilkan pada proses embedding sebelumnya kemudian digunakan untuk memperoleh nilai-nilai eigentriple yang dibutuhkan pada tahap singular value decomposition. Langkah awal yang dilakukan pada tahapan SVD adalah membentuk matriks $S=T_{x} T_{x}{ }^{T}$. Langkah selanjutnya adalah memperoleh nilainilai eigentriple:

- Singular Value $\left(\sqrt{\lambda_{i}}\right)$

Singular value merupakan hasil dari akar kuadrat eigenvalue pada matriks $S=T_{x} T_{x}{ }^{T}$. Nilai eigenvalue dan singular value yang diperoleh adalah sebagai berikut :

Tabel 2. Nilai Eigenvalues dan Singular Values

\begin{tabular}{|c|c|c|}
\hline No. & Eigenvalues & Singular Values \\
\hline 1 & 792368147881 & 890150.632 \\
\hline 2 & 1747884039 & 41807.703 \\
\hline$\vdots$ & $\quad \vdots$ & $\vdots$ \\
\hline 20 & 2570713 & 1603.344 \\
\hline
\end{tabular}

- Eigenvector $\left(U_{i}\right)$

Setelah mendapatkan nilai singular value maka selanjutnya dilanjutkan ke tahap perhitungan nilai eigenvector. Tahapan ini bertujuan untuk mempermudah pemilihan karakteristik dari data. Dari hasil perhitungan didapatkan nilai eigenvector sebagai berikut :

Tabel 3. Nilai Eigenvectors

\begin{tabular}{|c|c|c|c|c|c|}
\hline No. & $U_{1}$ & $U_{2}$ & $U_{3}$ & $\ldots$ & $U_{20}$ \\
\hline 1 & -0.2092041 & 0.30868142 & 0.009424004 & $\ldots$ & 0.08707780 \\
\hline 2 & -0.2086041 & -0.06913445 & 0.331638550 & $\ldots$ & -0.03831941 \\
\hline$\vdots$ & $\vdots$ & $\vdots$ & $\vdots$ & $\ddots$ & $\vdots$ \\
\hline 20 & -0.2442256 & 0.36530317 & -0.037079073 & $\ldots$ & -0.22305066 \\
\hline
\end{tabular}

Kemudian setiap nilai eigenvector yang ada dibentuk menjadi grafik seperti berikut : 


\section{Eigenvectors}

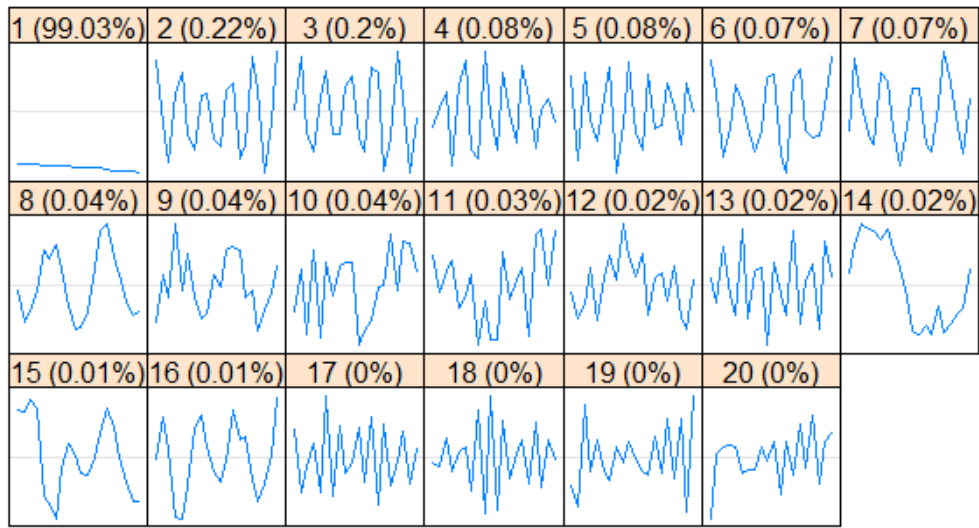

Gambar 1. Grafik Eigenvector

Pada Gambar 1 setiap nilai eigenvector di atas terlihat bahwa setiap eigenvector membentuk pola-pola tertentu. Hal ini memperlihatkan bahwa data hasil tangkap ikan di Provinsi Jawa Barat dari tahun 2004-2014 melibatkan beberapa komponen aditif. Oleh karena itu, untuk mempermudah identifikasi pola siklis dan musiman yang terbentuk sebaiknya dibentuk grafik dua dimensi eigenvector berpasangan.

Pairs of eigenvectors

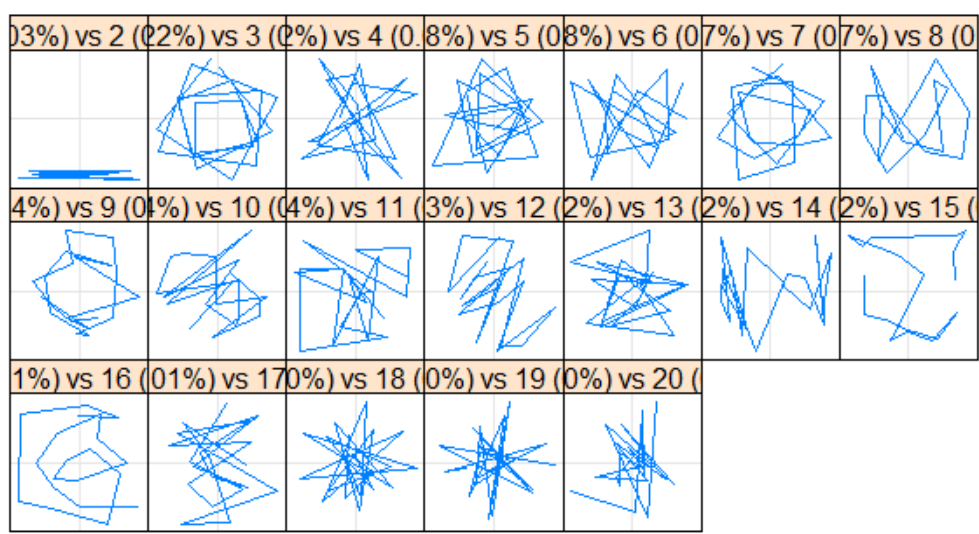

Gambar 2. Grafik Dua Dimensi Eigenvector Berpasangan

Berdasarkan grafik dua dimensi Eigenvector berpasangan pada Gambar 2 di atas, eigenvector ke-1 memiliki pola horisontal dan dijadikan sebagai kelompok pertama, namun untuk kelompok 
selanjutnya memiliki pola yang tidak beraturan sehingga untuk pengelompokan selanjutnya dilakukan melalui pengecekan periode untuk masing-masing eigenvector.

- $\quad$ Principal Component $\left(V_{i}\right)$

Nilai principal component dapat dihitung berdasarkan singular value dan eigenvector yang telah diketahui lebih dulu. Nilai principal component dapat dihitung dengan menggunakan persamaan

$$
V_{i}=\frac{T_{x}^{T} U_{i}}{\sqrt{\lambda_{i}}}
$$

Nilai principal component yang didapatkan nantinya bersifat mewakili keseluruhan proses dekomposisi yang telah dilakukan. Hal ini berdasarkan dari nilai masing-masing komponen sehingga dapat digunakan pada tahap grouping.

Tabel 4. Nilai principal component

\begin{tabular}{|c|c|c|c|c|}
\hline No. & $V_{1}$ & $V_{2}$ & $\ldots$ & $V_{20}$ \\
\hline 1 & -181127.6 & 12454.7931 & $\ldots$ & 71.42456 \\
\hline 2 & -181817.9 & 120.4136 & $\ldots$ & \\
\hline$\vdots$ & $\vdots$ & $\vdots$ & $\ddots$ & $\vdots$ \\
\hline 21 & -211946.6 & 2677.0791 & $\ldots$ & -344.81248 \\
\hline
\end{tabular}

\subsection{Rekonstruksi}

Tahapan rekonstruksi melibatkan 4 tahapan yaitu tahapan grouping, diagonal averaging, dan $R$-forecasting.

a. Grouping

Dengan menggunakan window length (nilai L) sebesar 20 dan didasarkan pada eigentriple, data perlu dibagi menjadi beberapa kelompok berdasarkan trial and error. Berdasarkan trial and error yang telah dilakukan, diperoleh parameter grouping yang optimal pada $m=4$, sehingga data dikelompokkan ke dalam 4 kelompok berdasarkan pola-pola yang ada. 
b. Diagonal Averaging

Tahapan akhir pada SSA adalah tahapan diagonal averaging. Pada tahap ini, akan dibentuk data deret dengan satu dimensi dan dengan panjang $N$ berdasarkan lima buah kelompok. Setiap kelompok yang ada akan direkonstruksi sesuai dengan pola kelompok masing-masing. Diagonal averaging dapat dihitung dengan menjumlahkan hasil rekonstruksi untuk tiap kelompok.

Tabel 5. Hasil Rekonstruksi

\begin{tabular}{|c|c|c|c|c|c|c|}
\hline \multirow{2}{*}{ No } & \multirow{2}{*}{ Data } & \multicolumn{4}{|c|}{ Hasil Rekonstruksi } & Diagonal Averaging \\
\cline { 3 - 7 } & & Horizontal & Periodik & Periodik & Siklis & \\
\hline 1 & 40221.61 & 37892.65 & 2860.058 & -111.366 & -478.549 & 40162.79 \\
\hline 2 & 42671.50 & 37910.51 & 1949.076 & 1760.174 & 928.039 & 42547.80 \\
\hline$\vdots$ & $\vdots$ & $\vdots$ & $\vdots$ & $\vdots$ & $\vdots$ & $\vdots$ \\
\hline 40 & 56892.68 & 51762.79 & 5425.604 & -194.709 & 47.194 & 57040.87 \\
\hline
\end{tabular}

c. $\quad$-forecastings

Algoritma pada peramalan $R$-forecasting berkaitan dengan penaksiran koefisien Linear Recurrent Formula (LRF) atau $a_{j}$ yang dihitung berdasarkan eigenvector pada tahap SVD. Data yang digunakan pada tahap $R$-forecasting adalah data hasil rekonstruksi pada tahap diagonal averaging.

Tabel 6. Koefisien Linear Recurrent Formula (LRF)

\begin{tabular}{|c|c|}
\hline$a_{1}$ & 0.097640356 \\
\hline$a_{2}$ & -0.327205165 \\
\hline$\vdots$ & $\vdots$ \\
\hline$a_{19}$ & -0.202024832 \\
\hline
\end{tabular}

Tahapan selanjutnya adalah peramalan untuk hasil tangkap ikan di Jawa Barat pada tahun 2014 untuk kuartal I, II, III, dan IV dengan model peramalan sebagai berikut:

$$
g_{k}=\left\{\begin{array}{c}
\bar{y}_{l} ; i=0,1, \ldots 19 \\
\sum_{j=1}^{20} a_{j} g_{i-j} ; i=41,42,43,44
\end{array}\right.
$$


Berdasarkan perhitnungan dengan model peramalan diatas maka dapat dihasilkan peramalan untuk hasil tangkap ikan di Provinsi Jawa Barat pada tahun 2014 untuk kuartal I, II, III dan IV.

Tabel 7. Hasil Peramalan untuk Data Outsample

\begin{tabular}{|c|c|c|}
\hline Kuartal & Data Aktual (Outsample) & Data Ramalan \\
\hline I & 47754.18 & 52203.15 \\
\hline II & 52418.77 & 52128.02 \\
\hline III & 50169.16 & 57462.12 \\
\hline IV & 55814.59 & 55626.19 \\
\hline
\end{tabular}

\subsection{Akurasi Peramalan}

Akurasi peramalan pada penelitian ini menggunakan nilai Mean Absolute Percentage Error (MAPE) dan tracking signal :

a. MAPE

Menurut Lewis (1982) di dalam Tsai (2012), jika MAPE bernilai kurang dari $10 \%$ maka hal ini menunjukkan bahwa metode peramalan yang digunakan sangat baik, sedangkan apabila nilai MAPE berada pada rentang 10\%-20\% maka metode peramalan yang digunakan baik. Nilai MAPE pada penelitian sebesar $6.19 \%$ artinya kurang dari 10\%, maka dapat disimpulkan bahwa metode peramalan dengan menggunakan metode Singular Spectrum Analysis (SSA) dengan window length 20 sudah sangat baik untuk meramalkan hasil tangkap ikan di Provinsi Jawa Barat.

b. Tracking Signal

Tahapan selanjutnya untuk menguji keandalan peramalan adalah dengan melihat nilai tracking signal. Batas toleransi nilai tracking signal yang diterima adalah \pm 5 (Bovas dan Ledolter,1983).

Tabel 8. Nilai Tracking Signal

\begin{tabular}{|c|c|c|c|}
\hline Kuartal & Data Aktual (Outsample) & Data Ramalan & Tracking Signal \\
\hline I & 47754.18 & 52203.15 & -1 \\
\hline II & 52418.77 & 52128.02 & -1.7201 \\
\hline III & 50169.16 & 57462.12 & -2.8336 \\
\hline IV & 55814.59 & 55626.19 & -3.6239 \\
\hline
\end{tabular}


Dari tabel 8 terlihat bahwa nilai tracking signal berada dalam batas toleransi sehingga metode peramalan SSA masih bisa digunakan untuk meramalkan $m$ periode waktu ke depan.

\subsection{Hasil Ramalan}

Tahapan selanjutnya adalah melakukan peramalan hasil tangkap ikan di Provinsi Jawa Barat tahun 2015. Hasil peramalan menggunakan metode SSA untuk kuartal I hingga kuartal IV adalah sebagai berikut:

Tabel 9. Hasil ramalan menggunakan SSA

\begin{tabular}{|c|c|}
\hline Kuartal & Hasil Ramalan \\
\hline I & 53978.49 \\
\hline II & 54406.91 \\
\hline III & 50889.11 \\
\hline IV & 56896.96 \\
\hline
\end{tabular}

\section{KESIMPULAN DAN SARAN}

Proses peramalan terhadap data hasil tangkap ikan di Provinsi Jawa Barat telah dilakukan menggunakan metode yaitu metode SSA. Akurasi hasil ramalan dihitung menggunakan MAPE. MAPE dari ramalan untuk metode SSA adalah $6.19 \%$. Berdasarkan nilai MAPE tersebut, maka dapat dikatakan metode SSA cocok digunakan pada peramalan selanjutnya. Hasil ramalan untuk produksi perikanan tangkap di provinsi Jawa Barat tahun 2015 untuk kuartal I adalah 53.978,49 Ton, kuartal II 54.406,91 Ton, kuartal III 50.889,11 Ton, dan kuartal IV 56.896,96 Ton.

\section{DAFTAR PUSTAKA}

Amdayani, N. J., Penentuan Window Length (L) Terbaik pada Metode Singular Spectrum Analysis (SSA), Skripsi, Program Studi Statistika, FMIPA Universitas Padjadjaran, 2016.

Abraham, B. dan Ledolter, J., Statistical Method for Forecasting, John Wiley and Son Inc., New York, 1983. 
Fitri, F., Aplikasi Autoregressive Distributed Lag Modelling pada Data Produksi Perikanan Tangkap dan Intensitas Curah Hujan di Provinsi Jawa Barat, Skripsi, Program Studi Statistika, FMIPA Universitas Padjadjaran, 2016.

Golyandina, N., Nekrutkin, V., dan Zhigljavsky, A., Analysis of Time Series Structure: SSA and Related Technique, Chapman \& Hall, London, 2001.

Kementerian Perikanan dan Kelautan.

Khan, M. A. R. dan Poskitt, D. S., Moment Tests for Window Length Selection in Singular Spectrum Analysis, Monash University, Australia, 2011.

Lewis, C. D., International and Business Forecasting Methods, Butterworths, London, 1982.

Liao, T. W., Clustering of Time Series Data-A Survey, Lousiana State University, Los Angeles, 2005.

Mulyana, Analisis Data Deret Waktu, Universitas Padjadjaran, Bandung, 2004.

Zhigljavsky, A., Singular Spectrum Analysis for Time Series: Introduction to This Special Issue, Statistics and Its Interface, 3 (2010). 
